\title{
Impact of Platon ETC system on intercity trucking cost
}

\author{
Natalya Pogotovkina ${ }^{1 *}$, Ekaterina Demakhina ${ }^{1}$, and Sergey Ugay ${ }^{1}$ \\ ${ }^{1}$ Far Eastern Federal University, Department of Transport Machinery and Transport-Technological Processes, Vladivostok, Russia
}

\begin{abstract}
In 2015 Platon ETC System, a system of charging trucks with gross vehicle weight exceeding 12 tons, was implemented in Russia. The payment is collected as a compensation fo 0 the damage caused to the federal public roads. Platon system is an additional source of financing for the road sector. However, its implementation made the carriers face the increasing costs. This paper presents the first results of the system functioning and the problems, associated with it. We consider the foreign systems of truck charging. The results of calculations, which show the effect of the toll collection on the prime cost of road freight transportation, are also presented.
\end{abstract}

\section{Prerequisites for toll imposition in the Russian Federation}

Haulage trucking is an integral part of state infrastructure. They allow making sales at various distances; contribute to the development of economic relations and growth of welfare of the country as a whole. A huge number of companies build their business on providing services for the cargo transportation at different levels of the administrative system from urban and regional down to international.

Road trucking accounts for about half of the volume of cargo traffic in the country. The constant increase in traffic flows and haulage intensifies usage of the road network. Traffic density, total weight, axle load and vehicles speeds are increasing, thus it leads to a rapid deterioration of road surface. Heavy trucks have a greater impact on the destruction of the pavement.

To generate additional financing for the construction, repair and maintenance of roads, "User pays" toll collection systems are implemented all over the world.

On November 15, 2015, the Russian Federation put Platon system into a force. This is a system of charge collection as the compensation for harm caused to the federal public roads by trucks with gross vehicle weight exceeding 12 tons. The name "Platon" derives from abbreviation of Russian phrase "plata za tonny" PLATON (it means pay for tons). Initially, it was planned to charge 3.73 rubles per 1 kilometer, but due to the mass protests that had swept the country before the system should come into effect the charge was reduced to 1.53 rubles per 1 kilometer [1].

\subsection{A brief review of the literature}

Having caused a massive public response, Platon system could not fail to catch the interest of researchers. A number of scientific papers have been published in just a year and a half from the system integration. Most of them are devoted to issues related to the performance of system, as well as the impact of a new road toll on the costs of carriers. Thus, the work of D.S. Anisimova and O.V. Psareva "The forecast of state revenues increase after the implementation of road toll for trucks over 12 tons" considers the problems, associated to road toll imposition, and analyze the state income and carriers costs arouse from the Platon system implementation [2]. A number of authors conducted a comparative analysis of the Platon system with its foreign counterparts in their works $[3,4]$. A.T. Naniev deals with the legal aspects of the charging system in Russia. He also raises the question of "double" compensation for harm causing to the road surface when transporting heavy cargo [5].

\subsection{The size and structure of the motor vehicle fleet in Russia}

Even Russian classics called roads one of the main Russian trouble. Throughout the history roads of Russia has been given insufficient attention. Dense forests and swamplands created certain difficulties in the construction of roads. The majority of Russian towns and villages was located along the riverbanks, where there was navigation in summer and sledding in winter.

However, the development of civilization and territorial expansion triggered the necessity of roads construction. Special significance of roads became apparent with the growth of territory in XVI-XVII centuries. The first mention about position of a stagecoach official, who was responsible for the condition of postal stations and roads, one can find in Charter of Ivan III, dated by June 6, 1481. Later in the XVIII century, Catherine II had treated the road building as the matter of national importance.

Industrial development and the occurrence of the first motor vehicles at the turn of XIX-XX centuries contributed to the change of government opinion on the

Corresponding author: pogotovkina.ns@dvfu.ru 
state of the roads. Russian motorization began in the early 30-ies of the last century with the construction of the plant in Nizhny Novgorod (later Gorky Automobile Plant), where the production of license conveyor automobiles had started. Before the 1970s, cars were considered as a luxury, and only the release of the famous car VAZ-2101 gave rise to the mass motorization of the country [6]. Since that time, the level of car ownership has increased more than 50 times and in July 2016 amounted to 287 cars per thousand inhabitants $[7,8]$. The motor vehicle fleet of the country has doubled only for the last 15 years (fig. 1).

$$
\begin{aligned}
& \text { vehicle } \\
& \text { quantity, } \\
& \text { mln. units }
\end{aligned}
$$

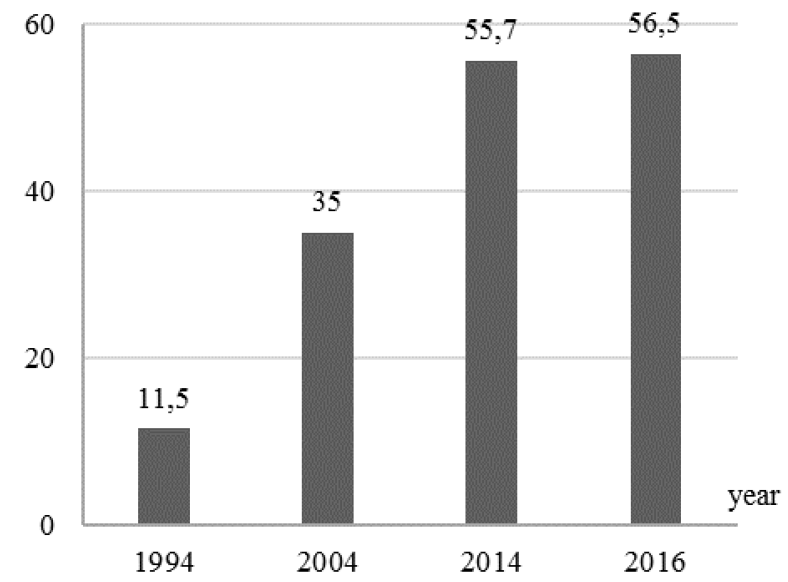

Fig. 1. The number of motor vehicle fleet, mln units.

The entire network of existing roads in Russia has been built since the beginning of the 60th to the 90th years of the last century. Since that time, the number of cars and trucks increased significantly. The influence of cars on the roads is not so much, but the same is not true for trucks.

According to the data of the Russian National Road Traffic Safety Inspectorate in December 2016 there were registered 56.6 million vehicles, including more than 44.2 million cars, and more than 6.2 million trucks (table 1) $[9]$.

Table 1. The number of truck fleet in the Russian Federation.

\begin{tabular}{|c|c|}
\hline Type of vehicle & $\begin{array}{c}\text { The number of vehicles, } \\
\text { un. }\end{array}$ \\
\hline Truck & $6,229,696$ \\
\hline Full trailer & $2,328,537$ \\
\hline Semi-trailer & 675,567 \\
\hline
\end{tabular}

Figure 2 demonstrates the structure of the truck fleet depending on the gross vehicle weight $(\mathrm{m})$.

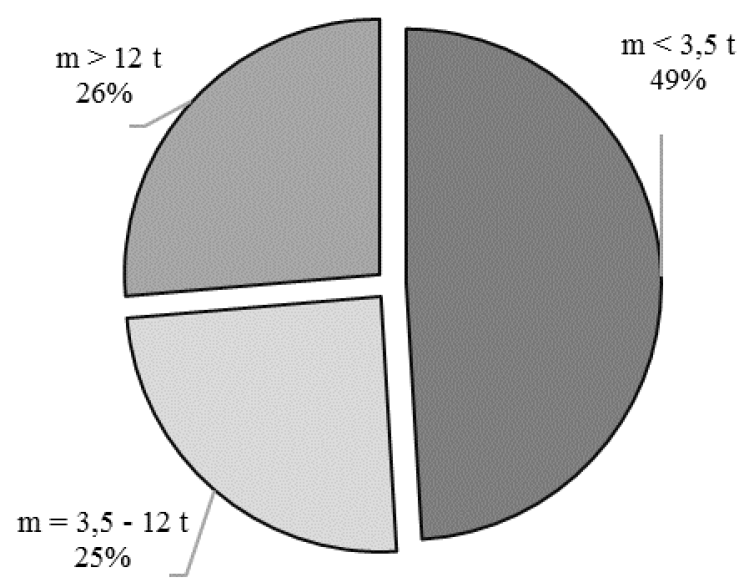

Fig. 2. Structure of the truck fleet in the Russian Federation.

As can be seen from the figure, $26 \%$ (which is $1,641,634$ units) of the total number of trucks has a maximum mass exceeding 12 tons. In addition, about 400 thousand foreign heavyweight trucks are constantly moving throughout the country. These 2 million trucks cause $56 \%$ of all pavement damage [10]. Road freight transport together with cars creates heavy load on the pavement. Cracks appear and turn into the potholes after a short period. It was estimated long ago that the major damage to road is caused by vehicles with gross mass exceeding 12 tons or more. Thus, one pass of a truck with an axial load of 10 tons is equivalent to the damage caused by passing from 10 to 25 thousand cars. Moreover, the trucks cause much greater damage to the environment as compared to cars [10].

\subsection{Condition of the road network of the Russian Federation}

Vehicle fleet is growing and give rise to the problems of road and transport infrastructure, from snow removal on out to the bridges collapse. The pavement quality leaves much to be desired; constant patching does not give proper results, "patches" do not serve long. There are several reasons for this phenomenon:

- Poor quality design, related to the age of the designers who were graduated from universities long ago and studied an outdated program, as well as their reluctance to advance the skills and adopt foreign countries experience;

- Corruption and the use of substandard construction materials, undersealing of soil and asphalt mixtures and violation of the other regulations, including asphalt laying under the conditions of snowing and sub-zero temperatures [11];

- Outdated regulations and normative documents;

- Lack of funding;

- Geographical and climatic factors;

- The inability of the majority of Russian roads to bear the load to which they are exposed.

Currently, the total length of public road network in the Russian Federation is 1452.2 thous. km, including: 
- 51.9 thous. $\mathrm{km}$ - federal roads;

- 515.8 thous. $\mathrm{km}$ - regional roads;

- 884.5 thous. $\mathrm{km}-$ local roads.

$8.1 \%$ of regional roads and $43.6 \%$ of local roads do not have hard surface. $64.4 \%$ of regional roads and $29 \%$ of local roads have an improved roadway pavement, capable to pass the flows of trucks, regardless of climatic conditions [12]. The density of road in the western (European) part of Russia is much higher than in the eastern part in the Far Eastern Federal District. Thus, in addition to road quality problems in Russia, there is also the problem of the number of roads, that is, the length of roads.

\section{Platon ETC system and its influence on the cost of cargo transportation}

On November 15, 2015, Platon Electronic Toll Collection (ETC) system began its work to facilitate and process the collection of toll charges from vehicles exceeding 12 tons of gross vehicle weight. Actually, it is a new source of financing for the road sector. The rules and procedure of charging are set by the Russian Government [13].

\subsection{Platon ETC system}

Trucking in Russia is not the most profitable business; it is mainly due to the geography of our country. Before the Platon system should come into force, the mass protests had swept the country, and it produced results. Initially, the project cost of travel was 3.73 rubles for one $\mathrm{km}$ of road, but from the first day, the charge rate was 1.5293 rubles per $\mathrm{km}$ (3.73 with a coefficient of 0.41 rubles $/ \mathrm{km})$. The reduced rate must have remained until 29 February 2016, but its validity was extended until April 15, 2017.

During the first days after the system starts working the process came with a variety of problems. Carriers had to return the trucks back from haul due to failure of the on-board device, they had to make extra schedules, but the system still gave a failure: the money multiply debited from accounts, reaching five to seven debiting [14]. There have also been cases of debiting the account of the car drive down a country road, parallel to the federal highway, or during the idle period.

The main result of a year's work of Platon system was the provision of 22.9 billion rubles to the Russian regions for road repair, as well as the construction and repair of bridges and highway-over crossings. For example, a third part of 230 city streets in Petrozavodsk was repaired at the expense of Platon system [15].

Most of the countries follows the principle of "user pays" to address the challenges of financing activities related to the road sector. In order to obtain profit, owners of trucks enjoy the useful properties of highways, inflicting excess damage. Charging system is introduced as the mean of compensation for this damage.

The EU countries have different charging systems, and the payers are different groups of vehicle owners. For example, Germany is charging the vehicles with the gross weight more than 7.5 tons [16], while Austria, Switzerland and the Czech Republic are charging the vehicles with gross weight more than 3.5 tons. Eurovignette time-based payment system was commissioned in early 1993, it operates in Belgium, Netherlands, Luxembourg, Denmark and Sweden. Eurovignette is a special sticker on the windscreen. It allows using the motorways in all countries, which have signed the agreement, within a certain period. Differentiation of payments also depends on the number of axles and the vehicle environmental class [17]. The neighboring Belarus introduced a BelToll system of vehicle charging from August 1, 2013 [18]. There are 1,189 kilometers of toll roads in the country. The toll payments apply to vehicles over weight of 3.5 tons. The cost of travel amounts from 0.04 to 0.145 euros for $1 \mathrm{~km}$. Thus, the rates in all countries are different due to the different income levels and living standards, but the tariff in force in Russia is one of the lowest in the world. Despite this, a fee for each kilometer traveled has an impact on the prime cost of transport services.

\subsection{Trucking prime cost}

A prime cost of trucking is an expense of motor carrier to perform the transportation expressed in monetary terms. The structure of the transportation prime cost is a composition and ratio of expenditures and the cost of elements in the total operating expenses [19]. Figure 3 illustrates expenditures and their ratio in total cost of transportation [20].

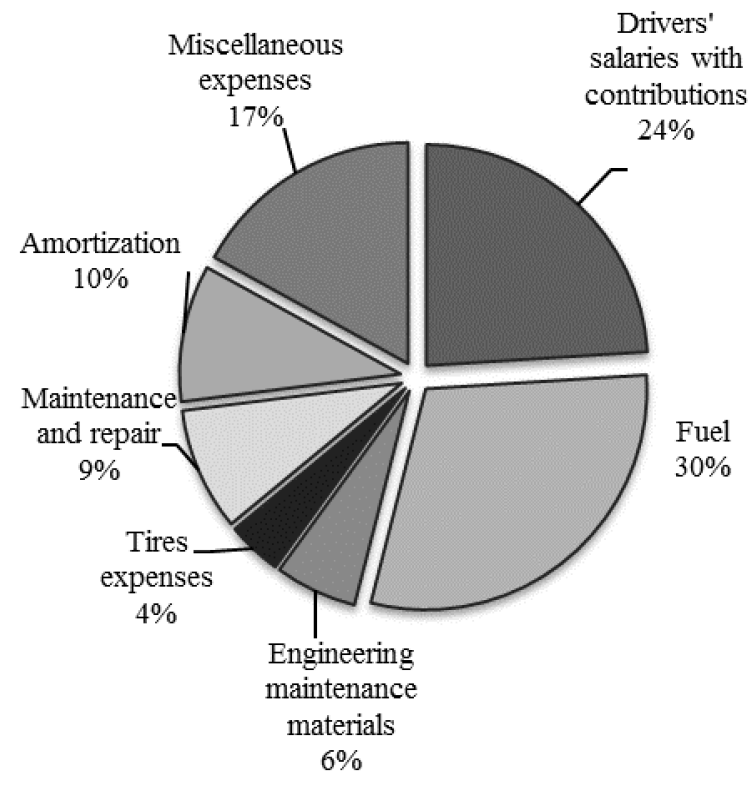

Fig. 3. Trucking expenses structure.

Miscellaneous expenses make up 15-30\% from all other expenditures and include:

- Salaries of all employees, except for driver;

- Utility fees;

- Insurance fees;

- Transport tax; 
- Safety inspection;

- Toll payments etc.

The introduction of Platon system entails additional costs and an increase in transportation prime costs on the miscellaneous expenses.

\subsection{The Impact of Platon ETC System on the Cost of Trucking}

The authors of this paper studied the influence of Platon system on the cost of road freight transportation. The largest volume of road freight transportation in Primorsky region accounts for local territory carriage and Far East region carriage. Currently, the largest cargo-points are the seaports of Primorsky region and a warehouse logistics center in the city of Artem, which was built only a few years ago. It is located on the federal highway A $370,5 \mathrm{~km}$ from the "Knevichi" airport and $35 \mathrm{~km}$ from the city of Vladivostok. To estimate the impact of Platon traffic toll system on the cost of the trucking we considered four most requested routes in Primorsky region (present numbering of the routes will be used hereafter):

1) Artem - Ussuriysk;

2) Artem - Khabarovsk;

3) Artem - Blagoveshchensk;

4) Artem - Yakutsk.

The starting point of the routes is a logistics warehouse complex in the Artem city.

All the considered routes partially pass on the highway A370. In addition, the track route ArtemYakutsk runs along the federal highway R297 ChitaKhabarovsk and A360 Never-Yakutsk. Table 2 shows the runs on the considered routes (L), the runs on the federal roads $\left(\mathrm{L}_{\mathrm{f}}\right)$, the runs on the regional and local roads $\left(L_{r}\right)$, and the ratio of the run on federal roads $\left(R_{f}\right)$ in total run of the route.

Table 2. Routes runs.

\begin{tabular}{|c|c|c|c|c|}
\hline Route & $\mathrm{L}, \mathrm{km}$ & $\mathrm{L}_{\mathrm{f}, \mathrm{km}}$ & $\mathrm{L}_{\mathrm{r}}, \mathrm{km}$ & $\mathrm{R}_{\mathrm{f}}, \%$ \\
\hline 1 & 82 & 64 & 18 & 78 \\
\hline 2 & 726 & 700 & 26 & 96 \\
\hline 3 & 1,470 & 1,300 & 170 & 88 \\
\hline 4 & 2,998 & 2,950 & 48 & 98 \\
\hline
\end{tabular}

Table 3 shows the costs and fees for one truck ride on each route, provided by the motor carrier company.
Table 3. Prime cost and tariff for a truck ride.

\begin{tabular}{|c|c|c|}
\hline Route & $\begin{array}{c}\text { Prime cost, } \\
\text { rub/truck ride }\end{array}$ & $\begin{array}{c}\text { Tariff, rub/truck } \\
\text { ride }\end{array}$ \\
\hline 1 & 12.050 & 13.500 \\
\hline 2 & 43.256 & 50.000 \\
\hline 3 & 73.042 & 90.000 \\
\hline 4 & 222.358 & 279.000 \\
\hline
\end{tabular}

After the introduction of Platon system the miscellaneous expenses article include tolls on federal roads, which increases the overall cost of transportation. Now the rate for 1 travelled $\mathrm{km}\left(\mathrm{P}_{\mathrm{km}}\right)$ equals to 1.53 rubles, when the tax concession period ends and tariff raises it will be 3.06 rubles.

Toll for travel on federal road:

$$
\mathrm{P}_{\mathrm{f}}=\mathrm{L}_{\mathrm{f}} \mathrm{P}_{\mathrm{km}} \text {. }
$$

The prime cost of transportation on route is the expenses on the truck ride performance $\left(\mathrm{C}_{t}\right)$. Prime cost of the transportation with account of toll for federal road travel

$$
\mathrm{C}_{\mathrm{t} \text { pay }}=\mathrm{C}_{\mathrm{t}}+\mathrm{P}_{\mathrm{f}}
$$

Trucking prime cost increase.

$$
\mathrm{P}_{\text {toll }}=\mathrm{P}_{\mathrm{f}} \cdot 100 / \mathrm{C}_{\mathrm{t}} \text {. }
$$

Table 4 shows the prime cost of travel on federal road for each route, counted for tax concession period and for normal period.

Table 4. Federal road toll.

\begin{tabular}{|c|c|c|c|}
\hline \multirow{2}{*}{ Route } & \multirow{2}{*}{$\begin{array}{c}\mathbf{C}_{\mathbf{t}}, \\
\text { rub/truc } \\
\mathbf{k} \text { ride }\end{array}$} & \multicolumn{2}{|c|}{ Truck ride cost increase, \% } \\
\cline { 3 - 4 } & $\mathrm{P}_{\mathrm{km}}=1.53 \mathrm{rub} / \mathrm{km}$ & $\mathrm{P}_{\mathrm{km}}=3.06 \mathrm{rub} / \mathrm{km}$ \\
\hline 1 & 12,050 & 0.81 & 1.62 \\
\hline 2 & 43,256 & 2.47 & 4.95 \\
\hline 3 & 73,042 & 2.72 & 5.45 \\
\hline 4 & 222,358 & 2.03 & 4.06 \\
\hline
\end{tabular}

The table 4 demonstrates that the implementation of Platon toll collection system causes an increase in trucking cost in the range of 0.8 to $2.7 \%$ within the existing (preferential) rate and from $1.6 \%$ to $5.4 \%$ in the case of an increase rate to 3.06 rubles $/ \mathrm{km}$.

Figure 4 illustrates the comparison of prime costs with different tariff rates for federal road travel. 


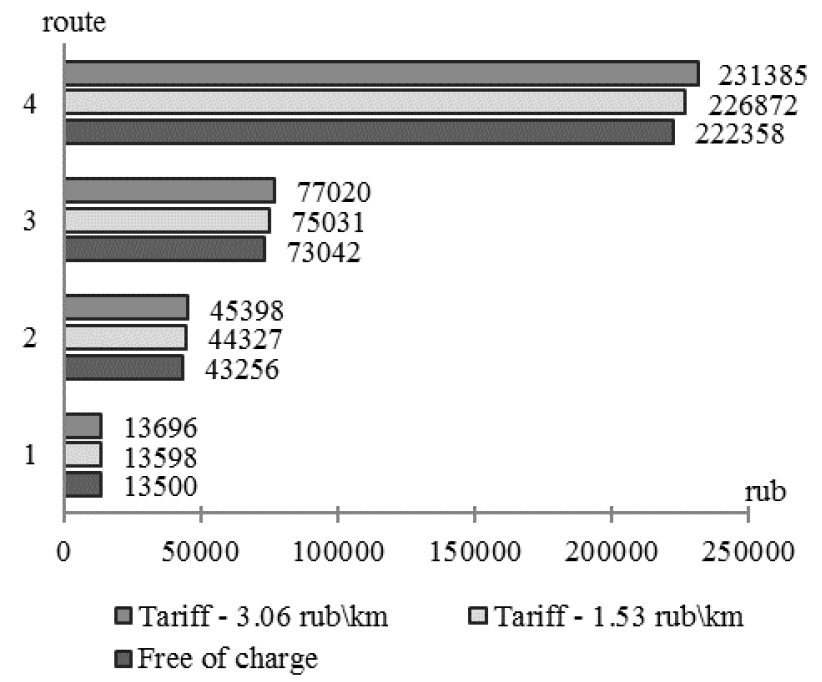

Fig. 4. Trucking prime costs changings caused by Platon ETC system

Thus, the introduction of Platon ETC system leads to an increase in the cost of road freight transportation. The increase in cost results in an increase in tariffs that affects the value of all goods from food and medicine on down to the raw materials, resources and components. As a result, a final consumer of goods and services suffers.

In addition, the increase of the final product cost results in the raise of value added tax, and it turns out that the money goes twice to state budget.

\section{Conclusion}

Making a conclusion, we have to notice that the complaints of carriers, caused by road toll imposition, are justified. However, it is an additional source of road sector financing. It is obvious that the road conditions motor vehicles are to operate under have significant effect on the cost of transportation. Poor road conditions increases fuel and lubricants consumption, advances tire wear. It also causes frequent maintenance of motor vehicles; it is necessary to repair trucks more often. Thus, if the funds collected through the Platon system are aimed on improvement of the roads condition, the owners of freight vehicles will save on repairs of automobiles, spare parts and fuel while using the federal roads.

\section{References}

1. Electronic Toll Collection System (Platon). Retrieved on January 25, (2017). http://platon.ru/ru/about/

2. D.S. Anisimova, O.V. Psareva, Prospects for development and improvement, 1, 18-22 (2016)

3. Y.S. Karpova, V.V. Lanskih, Materials of the PNU 56th Student Scientific and Practical Conference breakout sessions, 2, 125-129 (2016)

4. I.V. Biryukova, Actual problems of modern Russian economy, 3, 200-205 (2016).
5. A.T. Naniev, Problems of damages recovery in the Russian legal order: collection of articles of the VI annual international research and practical conference, 465-474 (2016).

6. Page of the history of Russian Roads (JSC "Road Operator Enterprise no. 7"). Retrieved on November 20, (2016). http://m7dep7.ru/stranichka-istoriidorog-rossii/

7. Cars ownership rating of Russian regions (Autostat Analytic Agency). Retrieved on January 15, (2017). https://www.autostat.ru/press-releases/27115/

8. G.I. Klinkovshtein, M.B. Afanas'ev, Organization of traffic (Transport, Moscow, 2001)

9. Information about the road safety indicators. In Road Traffic Police (2017). http://www.gibdd.ru/stat/

10. The goods adjusted for truck (Platon ETC System). Retrieved on January 19, (2017). http://platon.ru/ru/smi/26-10-2015/3640/

11. Asphalt laying during snowfall to be traditional in Russia (Vladivostok city site). Retrieved on January (2017). http://www.newsvl.ru/ggg/2016/11/26/153908/

12. The road infrastructure development. A reference to the teleconference call on measures to improve the state of regional and local roads (The Russian Government site). Retrieved on January 25, (2017). http://government.ru/info/22865/

13. Order of the Government of the Russian Federation of June 14, 2013 No. 504. About collection of the payment on account of the indemnification caused to highways of federal importance by the vehicles having the permitted maximum weight over 12 tons (Garant Database). Retrieved on December 9, (2016). http://base.garant.ru/70397412/

14. Platon-3: system failure, carriers complaints and first millions (PPT.RU). Retrieved on January 20, (2017). http://ppt.ru/news/134727

15. A year of Platon system execution: regional roads get 22.9 bln rubles (Platon ETC System). Retrieved on January 27, (2017). http://platon.ru/ru/frontpage/15-11-2016/5981/

16. Truck toll collection in Germany (Tollcollect). Retrieved on January 15, (2017). http://www.vdnk.ru/site/ru/transport-articles/tollroads

17. Road toll (VDNK Cargo Transportation). Retrieved on January 15, (2017). http://www.vdnk.ru/site/ru/transport-articles/toll$\underline{\text { roads }}$

18. Belarus electronic toll collection system (BelToll official site). Retrieved on January 15, (2017). http://www.beltoll.by/

19. O.N. Larin, Cargo transportation arrangement (SUSU, Chelyabinsk, 2006)

20. N.S. Pogotovkina, Road cargo trucking (FEFU Publishing, Vladivostok, 2012) 